\title{
Evaluation of Serum Zinc Levels in Cattle with Trichophytosis According to Extensiveness of Trichophytosis
}

\author{
Taner Şimay ${ }^{1, a}$, Basaran Karademir ${ }^{2, b, *}$ \\ ${ }^{1}$ Ministry of Agriculture and Forestry, District Directorate of Agriculture, 36760 Susuz/Kars Turkey \\ ${ }^{2}$ The School of Applied Sciences, The University of Iğdır, 76000 Iğdır, Turkey
}

*Corresponding author

\begin{tabular}{|c|c|}
\hline A R T I C L E I N F O & A B S T R A C T \\
\hline $\begin{array}{l}\text { Keywords: } \\
\text { Trichophytosis } \\
\text { Extensiveness } \\
\text { Serum } \\
\text { Zinc } \\
\text { Level }\end{array}$ & $\begin{array}{l}\text { This study aimed to reveal relationship between the extensiveness of trichophytosis on the body and } \\
\text { serum zinc levels in cattle. This study was carried out on } 92 \text { cattle with trichophytosis and } 50 \text { healthy } \\
\text { ones. Serum zinc levels of healthy cattle were evaluated as control. The cattle with trichophytosis } \\
\text { separated into } 5 \text { groups according to diffusiveness of the diseases. Experimental groups of this study } \\
\text { were designed as follows; Group } 1: \text { up to } 1 \mathrm{~cm} \text {, Group } 2: 1-5 \mathrm{~cm} \text {, Group } 3: 5-10 \mathrm{~cm} \text {, Group } 4: 10 \text { - } \\
20 \mathrm{~cm} \text { and Group } 5: \text { widespread on the body. Serum zinc levels measured by atomic absorption } \\
\text { spectrophotometer equipped with flame system. In general, the mean level of } \mathrm{Zn} \text { in trichophytosis } \\
\text { groups ( } 0.613 \pm 0.013 \mathrm{mg} \mathrm{Zn} / \mathrm{L}) \text { was statistically lower than healthy ones }(0.900 \pm 0.017 \mathrm{mg} \mathrm{Zn} / \mathrm{L}) \text {. } \\
\text { A negative correlation was determined between the diffusiveness degree of trichophytosis and } \\
\text { serum zinc levels ( } \mathrm{r}=-0.772) \text {. Serum Zinc levels were statistically decreased from the control group } \\
\text { to group } 3 \text {. However, a stable course was observed from } 3 \text { to } 5 \text {. Therefore, the value of group } 3(0.6 \\
\text { mgZn/L) was determined as a critical value for the cattle with trichophytosis. According to } \\
\text { regression analysis results, it was observed that the extensiveness of the trichophytosis lesions } \\
\text { affected the levels of serum } \mathrm{Zn} \text { levels significantly }\left(\mathrm{r}^{2}=59.6 \% \text { ). Consequently, serum zinc levels of }\right. \\
\text { cattle decreased in an inversely proportional manner to the diffusiveness degree of trichophytosis } \\
\text { and stabilization was observed at the level of } 0.6 \mathrm{mg} \mathrm{Zn} / \mathrm{L} \text {. }\end{array}$ \\
\hline
\end{tabular}

\section{Introduction}

Trichophytosis, named as Dermatophytosis, Ringworm, Tinea, is a fungal skin diseases located on keratinoused tissues of skin and/or hairs (Nisbet et al., 2006; Zamani et al., 2016) Principal agents of this disease are Trichophton verrucosum. T. megnini and $\mathrm{T}$. mentagrophytes on cattle. T. verrucosum, is the most common factor in cattle and it is zoonosis. (Al-Janabi and Bashi, 2018; Ming, et al., 2006; Nisbet et al., 2006; Shokri and Khosravi, 2016).

Lesions, which are roughly circle having about $3 \mathrm{~cm}$ diameter, gray-white plaque, are mostly seen in the head, neck and perineum region. At the first stage, lesions appear wet and dampy, later crusts are being and then baldness is formed out, there is no itching (Ming, Ti, and Bulmer, 2006; Nisbet et al., 2006; Shams-Ghahfarokhi et al., 2009; Shokri and Khosravi, 2016; Zamani et al., 2016).

The defense systems of the organism must be insufficient for being effective of fungal agents on animal organisms (Ballou and Wilson, 2016; Guo et al., 2011). However, it is observed on the cattle which are kept in the closed moist barn for a long period in the winter season (Altınbaş et al., 2018; Nisbet et al., 2006; ShamsGhahfarokhi et al., 2009; Sharma et al., 2012; Shokri and Khosravi, 2016; Zamani et al., 2016).

Trace minerals are essential elements to be taken from outside to the body for many functions to take place (Ballou and Wilson, 2016; Karademir, 2017; Koc et al., 2018; Kuru et al., 2018a). In general, trace mineral levels in the body are affected by a lot of situations (nutritional deficiency, transportation, infectious diseases and similar stress cases) (Karademir, 2011; Kuru et al., 2018b; Lee et al., 2016; Malavolta et al., 2010; Patiño-Herrera et al., 2018; Pizent et al., 2010; Wu et al., 2011).

Zinc contributes to the structure of numerous Metalloenzymes, which are of metabolic importance. It is a cofactor of the superoxide dismutase enzyme acting against oxidative agents (Montllor-Albalate et al., 2018; Robinett et al., 2018). It is reported that zinc has an essential role in vitamin A transport mechanism in the body (Wu et al., 2011). Zinc is also very important for the 
functioning of the immune system (Al-Qudah et al., 2010; Ballou and Wilson, 2016; Finelt and Kenner-Bell, 2017; Wilson et al., 2012).

Zinc deficiency as skin-related disorders alopecia, skin and hair structure disorders, hair loss, skin dandruff and abnormal keratinization, causes delays in wound healing (Al-Refu, 2017; Ballou and Wilson, 2016; Finelt and Kenner-Bell, 2017). It is also reported that fungal agents may be more easily replicated in keratinized tissues. For these reasons, zinc deficiency causes increased susceptibility to mycotic infections in the skin (Altınbaş et al., 2018; Sharma et al., 2012; Shokri and Khosravi, 2016).

There are many studies to investigate the relationship between serum $\mathrm{Zn}$ level and fungal dermatitis. Most of them reported that serum Zinc levels decrease during dermatophytosis (Al-Qudah et al., 2010; Al-Refu, 2017; Malavolta et al., 2010; Miraloglu et al., 2016; Nisbet et al., 2006; Pizent et al., 2010; Y1ldırım et al., 2010). But no research was found to show the relationship between the diffusiveness of trichophytosis (the seriousness of the disease) and serum zinc levels in cattle. The aim of this study was to investigate the effect of extensity level of trichophytosis on the serum zinc level in cattle.

\section{Materials and Methods}

\section{Ethical Approval}

This study was conducted pursuant to the approval of the Local Ethics Board for Animal Experiments of Kafkas University (KAÜ-HADYEK, Approval number: 2012/028).

\section{Animal Material}

This study was carried out on 142 subjects, reared by local farmers (Male: 69, Female: 73; Brown Swiss cross breeds: 61, Simmental: 20; Simmental cross breeds: 24; native cross breeds: 37 ; 0-12 mounts ages), 92 of them are infected cattle with trichophytosis and other 50 cattle were healthy for the control group in Kars province of Turkey.

\section{Diagnose and Gradation}

For the confirmation of the clinical findings, skin scrapes were taken from lesions and mushroom sports were seen microscopically, using $10 \% \mathrm{KOH}$. Healthy cattle for control groups were selected from the same barns with infected ones. The ranking of infected cattle was done according to table one (Yildırım et al., 2010).

If the sum of the lesions will be considered to be a circle, the size of the lesions will approximate according to diameter basis.

\section{Blood Collections and Storage}

One shoot blood collections were made from the Jugular vein into $8.5 \mathrm{ml}$ vacuumed dry tubes (BD Vakutainer ${ }^{\circledR}$, Tipkimsan, Turkey). After the separations of serum (3500 rpm, $15 \mathrm{~min})$, samples were stored at $-20^{\circ} \mathrm{C}$ till mineral analyses.

\section{Laboratory Procedures}

Atomic Absorption Spectrophotometer equipped with Flame System (FAAS) was used for the serum $\mathrm{Zn}$ level detections (Thermo Elemental S4® Thermo Elecron Coorporation, Great Britain). Standard solution of Zn, required for the calibration of the FAAS was purchased from Fluka Chemie GmbH, Switzerland, with the stock number of 96457. As a dilution solution, deionized distilled water was used.

\section{Reliability of the FAAS Measurements}

To confirm the accuracy of the measurements, measurement of the diluted standard solution was performed once for each 5 samples. Obtained data were used for the calculation of the coefficient of variation $(\mathrm{CV})$. For various concentrations, $\mathrm{CV}$ calculations were as follows; for $0.25 \mathrm{ppm} \mathrm{Zn}: 5.18 \%$, for $0.5 \mathrm{ppm} \mathrm{Zn}$ : $2.86 \%$, for $1 \mathrm{ppm} \mathrm{Zn} 1.03 \%$ and $2 \mathrm{ppm} \mathrm{Zn}$ : $0.81 \%$.

\section{Statistical Analyses}

Homogeneity and Normality (Shapiro-Wilk test) test results of the data were $\mathrm{P}>0.05$. The difference between infected and control groups was compared by 2 -sample-t test. Counts of diffusiveness of groups were analyzed by the chi-square test. The relationship between trichophytosis diffusiveness groups and serum $\mathrm{Zn}$ levels was examined by the Correlation test. One-Way Analysis of Variance (ANOVA) with Tukey's honestly significant difference (HSD) test was employed for the comparisons of classification groups. The effect of the Trichophytosis extensity on the serum $\mathrm{Zn}$ levels was investigated by Regression analyses. Study data were presented as Mean \pm Standard Error Mean (SEM).

\section{Results}

In General, difference between the serum $\mathrm{Zn}$ levels of cattle with trichophytosis $(0.613 \pm 0.013 \mathrm{mg} \mathrm{Zn} / \mathrm{L})$ and healthy ones $(0.9 \pm 0.017 \mathrm{mg} \mathrm{Zn} / \mathrm{L})$ were statistically significant $(\mathrm{P}<0.001)$.

A total of 92 cattle with Trichophytosis were distributed to 5 groups according to the diffusiveness of the disease. According to the extensiveness classification, group counts, proportions and statistical comparisons were given in Table 2.

Table 1. Classification regarding lesion size

\begin{tabular}{|c|c|}
\hline $\begin{array}{l}\text { Ranking Cods } \\
\text { (Groups) }\end{array}$ & $\begin{array}{l}\text { Lesion } \\
\text { Size }\end{array}$ \\
\hline 0 & Control (Healthy) \\
\hline 1 & Cases up to $1 \mathrm{~cm}$ \\
\hline 2 & Cases from 1 to $5 \mathrm{~cm}$ \\
\hline 3 & Cases from 5 to $10 \mathrm{~cm}$ \\
\hline 4 & Cases from 10 to $20 \mathrm{~cm}$ \\
\hline 5 & Cases that are too common to measure \\
\hline
\end{tabular}

Table 2. According to count, proportions and chi-square test result of trichophytosis groups.

\begin{tabular}{c|cc}
\hline Groups & $\mathrm{n}$ & $\%$ \\
\hline 1 & $8^{\mathrm{d}}$ & 8.70 \\
2 & $11^{\mathrm{bcd}}$ & 11.96 \\
3 & $32^{\mathrm{a}}$ & 34.78 \\
4 & $21^{\mathrm{ab}}$ & 22.83 \\
5 & $20^{\mathrm{ac}}$ & 21.74 \\
\hline Total & 92 & 100 \\
\hline a.b,c.
\end{tabular}
superscript at the same column $(\mathrm{P}<0.01)$ 
The serum $\mathrm{Zn}$ level and the lesion size were inversely proportional as seen in Figure 1. The correlation analysis was performed in order to confirm the relationship between these two criteria and a significant negative correlation was detected between lesion size and serum $\mathrm{Zn}$ level $(\mathrm{r}=$ 0.772; $\mathrm{P}<0.001)$. According to detailed correlation test results, a significant negative correlation was found between groups' lesion size of first 4 groups (including group 3) and their serum $\mathrm{Zn}$ levels ( $\mathrm{r}=-0.774$; $\mathrm{P}<0.001$ ) but any correlation was not observed between other groups (group 3 and 5) and their serum $\mathrm{Zn}$ levels ( $\mathrm{r}=-0.164$; $\mathrm{P}>0.05)$.

Regression analysis was performed to reveal how the size of the lesion affects serum zinc levels. It was observed that serum $\mathrm{Zn}$ levels were affected by lesion size, significantly $\left(\mathrm{r}^{2}=59.6 \%, \mathrm{P}<0.001\right)$ and the regression equation is below;

\section{Serum mg Zn/L $=0.879-0.0757 \times$ Lesion Size}

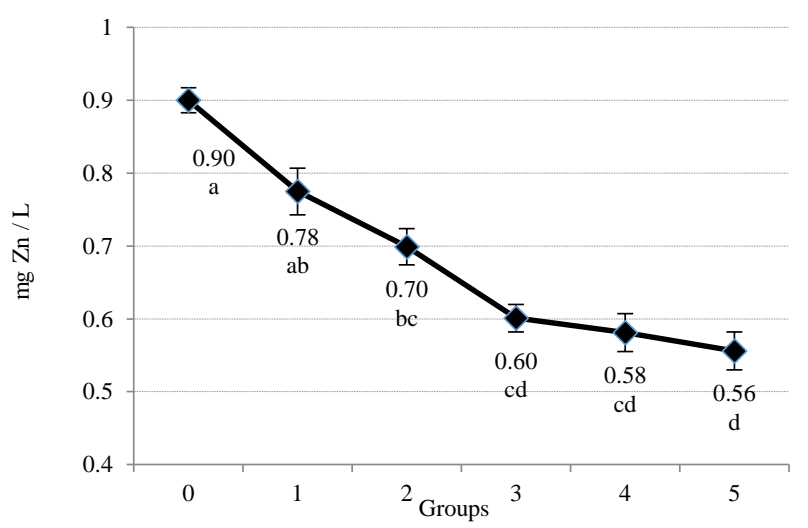

Figure 1. Serum $\mathrm{Zn}$ levels according to lesion size with statistical evaluation (Mean \pm SEM)

a.b.c: No statistical difference between the values having the same superscript $(\mathrm{P}<0.001)$

\section{Discussion}

As is known, zinc has important roles within animal organisms (Ali et al., 2017; Lee et al., 2016). In the case of $\mathrm{Zn}$ deficiency, numerous problems occur in the organism. (Al-Refu, 2017; Finelt and Kenner-Bell, 2017; Kincaid, 2000). Normal serum $Z n$ levels for animals are reported as $0,8-1,2 \mathrm{mg} / \mathrm{L}$. If serum zinc levels fall below $0.8 \mathrm{mg} / \mathrm{L}$, it causes symptoms due to zinc deficiency (Han et al., 2016; Karademir and Y1lmaz, 2018; Kincaid, 2000; Kuru et al., 2018a). In cases of stress caused by diseases, zinc levels in the blood and skin decreased, liver zinc storage rate has been reported to increase (Al-Qudah, Gharaibeh, and AlShyyab, 2010; Guo et al., 2011; Miraloglu et al., 2016; Pizent et al., 2010). It is also reported that zinc has important roles in skin physiology and negatively affects the health of the skin especially against fungal attack in its deficiency (Finelt and Kenner-Bell, 2017; Lee et al., 2016; Nisbet et al., 2006; Subramanian Vignesh et al., 2013). Besides, some researchers reported that fungal microorganisms need $\mathrm{Zn}$ for their vital activities and the host organism may require a low serum $\mathrm{Zn}$ level (Ballou and Wilson, 2016; Potrykus et al., 2014; Wilson et al., 2012) These study findings are consistent with the previous works.
In this study, the difference between the control group and the trichophytosis group was highly significant $(\mathrm{P}<0.001)$. Serum $\mathrm{Zn}$ levels of cattle with trichophytosis were found to be low $(0.613 \pm 0.013 \mathrm{mg} / \mathrm{L})$ compared to control group $(0.9 \pm 0.017 \mathrm{mg} / \mathrm{L})$. Previously conducted similar studies on fungal dermatophytosis generally supported the findings of this study. As a summary, in all of these studies, excluding a limited number of research (Aslan et al., 2010; Ural et al., 2009), serum zinc levels of the dermatophytosis groups have been reported to be statistically lower than the healthy ones (Al-Qudah et al., 2010; Al-Refu, 2017; Ballou and Wilson, 2016; Malavolta et al., 2010; Miraloglu et al., 2016; Nisbet et al., 2006; Pizent et al., 2010; Potrykus et al., 2014; Subramanian Vignesh et al., 2013; Wilson et al., 2012; Y1ldırım et al., 2010). In fact, Ural et al. (2009) found a decrease in animals with fungal dermatitis numerically. But this difference was not significant statistically. The results of Ural et al. (2009) may be due to the limited number of subjects. In this study, the number of healthy control group animals was 50 and according to laboratory findings including both clinical and microscopic examinations, the number of animals with fungal dermatitis was 92. If the number of subjects is to be compared with the above study data, it is quite convenient. Aslan et al. (2010) presented their data as "median" not mean of serum $\mathrm{Zn}$ level. Therefore, it is not possible to compare Ural et al. (2009) and data of this study. Therefore, comparing of their data with this study was impossible. Even dermatophytosis that are treated with $\mathrm{Zn}$ applications are available in numerous studies (Al-Janabi and Bashi, 2018; Lee et al., 2016; Patiño-Herrera et al., 2018).

Until this time, a large number of studies have been reported to address the relationship between dermatophytosis and serum zinc levels (Al-Qudah et al., 2010; Al-Refu, 2017; Malavolta et al., 2010; Miraloglu et al., 2016; Nisbet et al., 2006; Pizent et al., 2010; Potrykus et al., 2014; Subramanian Vignesh et al., 2013; Wilson et al., 2012; Wu et al., 2011; Yıldırım et al., 2010). However, there was no study to investigate the relationship between the lesion size of trichophytosis (the seriousness of the disease) and serum $\mathrm{Zn}$ levels.

Therefore, the principal aim of this study was to investigate the effect of lesion size on serum $\mathrm{Zn}$ levels. According to the data obtained, a reverse proportional situation was observed in general $(\mathrm{r}=-0.772 ; \mathrm{P}<0.001)$. But in detail, correlation was stronger until the $3^{\text {rd }}$ Group (Groups 0-3) ( $\mathrm{r}=-0.774 ; \mathrm{P}<0.001)$. But no important correlation was found the last three groups' lesion sizes (Groups 3-5) and serum $\mathrm{Zn}$ levels levels ( $\mathrm{r}=-0.164$; $\mathrm{P}>0.05)$. In the same way, significant differences were found between groups from 0 to 3 in various degrees. But, there was no statistical difference between groups' values from 3 to 5 (P>0.05). Zinc level at the $0.6 \mathrm{mg} / \mathrm{L}$ was observed as a critical level in group 3. After this point, lesion size has been effective on $\mathrm{Zn}$ level unimportantly (Figure 1). Even though the severity of the disease increased after this level, it was observed that the decrease in serum $\mathrm{Zn}$ level was not the same. This situation is contrasted with the findings of the previously reported studies with lower levels of serum zinc levels compared to healthy subjects (Al-Qudah et al., 2010; Al-Refu, 2017; Ballou and Wilson, 2016; Malavolta et al., 2010; Miraloglu et al., 2016; Nisbet et al., 2006; Pizent et al., 2010; 
Potrykus et al., 2014; Subramanian Vignesh et al., 2013; Wilson et al., 2012; Wu et al., 2011; Yildırım et al., 2010).

The majority of 92 cattle with trichophytosis included in the study were in the $3 \mathrm{rd}$, 4th and 5 th groups as seen in the Table II. Although the serum Zn level $(0.6 \mathrm{mg} / \mathrm{L}) \mathrm{did}$ not decrease more after the third group, the disease was well spread on the body. It was found no statistical decrease from group 3 to group in 5 their serum $\mathrm{Zn}$ levels $(\mathrm{P}>0.05)$ and no correlation between these groups. This may be an indication that zinc deficiency and trichophytosis trigger each other.

Some literature about this complex situation as a paradox can be given as follows; numerous studies have reported that serum $\mathrm{Zn}$ levels decrease in animals with trichophytosis. (Al-Refu, 2017; Ballou and Wilson, 2016; Malavolta et al., 2010; Miraloglu et al., 2016, 2016; Nisbet et al., 2006; Potrykus et al., 2014; Subramanian Vignesh et al., 2013; Wilson et al., 2012; Y1ldırım et al., 2010). Again, some studies report that $\mathrm{Zn}$ deficiency facilitates fungal dermatitis (Al-Qudah et al., 2010; Altınbaş et al., 2018; Guo et al., 2011; Shokri and Khosravi, 2016; Wu et al., 2011; Zamani et al., 2016). It has been reported that zinccontaining applications contribute to the treatment of trichophytosis (Ali et al., 2017; Al-Janabi and Bashi, 2018; Lee et al., 2016; Patiño-Herrera et al., 2018).

\section{Conclusions}

Serum zinc levels were found lower in cattle with trichophytosis compared to controls. Negative correlation was found between the lesion size and serum $\mathrm{Zn}$ level. In this relationship, serum $0.6 \mathrm{mg} \mathrm{Zn} / \mathrm{L}$ was detected as critical point. A strong correlation was detected before this point, but not after that. Before this point, the difference between serum $\mathrm{Zn}$ levels of the groups was significant, but it was not significant between the groups after this point. The effect of the lesion size on serum $\mathrm{Zn}$ level was found to be strong.

\section{Acknowledgements}

The study, which is summarized from master thesis of Taner ŞIMAY, was presented as a poster at the XI. Congress of National Veterinary Internal Medicine on 2125 May 2015, Samsun/Turkey

\section{Statement of conflict of interest}

The authors declare no conflict of interest.

\section{References}

Ali SS, Morsy R, El-Zawawy NA, Fareed MF, Bedaiwy MY. 2017. Synthesized zinc peroxide nanoparticles ( $\mathrm{ZnO} 2-\mathrm{NPs})$ : A novel antimicrobial, anti-elastase, anti-keratinase, and antiinflammatory approach toward polymicrobial burn wounds. International Journal of Nanomedicine, 12: 6059-6073.

Al-Janabi AAHS, Bashi AM. 2018. Development of a new synthetic xerogel nanoparticles of silver and zinc oxide against causative agents of dermatophytoses. The Journal of Dermatological Treatment, 2018: 1-5.

Al-Qudah KM, Gharaibeh AA, Al-Shyyab MM. 2010. Trace minerals status and antioxidant enzymes activities in calves with dermatophytosis. Biological Trace Element Research, 136: $40-47$.
Al-Refu K. 2017. Hair loss in children, etiologies, and treatment. hair and scalp disorders. Edi: Kutlubay Z. and Serdaroglu S., Open Access Peer-Reivewed Chapter 14, INTECH. https://www.intechopen.com/books/hair-and-scalpdisorders/hair-loss-in-children-etiologies-and-treatment. (accessed 30 December 2018)

Altınbaş R, Özakkaş F, Barış A, Turan D, Şen S. 2018. In vitro susceptibility of seven antifungal agents against dermatophytes isolated in İstanbul. Turkish Journal of Medical Sciences, 48: 615-619.

Aslan Ö, Aksoy A, İça T. 2010. Dermatofitozisli genç sığırlarda serum çinko, bakır ve mangan seviyeleri. Erciyes Üniversitesi Veteriner Fakültesi Dergisi, 7: 29-33.

Ballou ER, Wilson D. 2016. The roles of zinc and copper sensing in fungal pathogenesis. Current Opinion in Microbiology, 32: $128-134$.

Finelt N, Kenner-Bell BM. 2017. Management of skin disorders of the newborn. In: Teng, J.M.C., Marqueling, A.L., Benjamin, L.T. (editors) Therapy in pediatric dermatology: management of pediatric skin disease. Springer International Publishing: Cham, pp:7-13. DOI: https://doi.org/10.1007/ 978-3-319-43630-2_2 (accessed 30 December 2018)

Guo CH, Chen PC, Yeh M-S, Hsiung DY, Wang CL. 2011. $\mathrm{Cu} / \mathrm{Zn}$ ratios are associated with nutritional status, oxidative stress, inflammation, and immune abnormalities in patients on peritoneal dialysis. Clinical Biochemistry, 44: 275-280.

Han Z, Li R, Li K, Shahzad M, Wang X-Q, Luo H, Qiu G, Nabi F, Li J, Meng X. 2016. Assessment of serum trace elements in diarrheic yaks (Bos grunniens) in Hongyuan, China. Biological Trace Element Research, 171: 333-337.

Karademir B. 2011. Effects of oral zinc sulfate applications at different $\mathrm{pH}$ (ascorbic acid, vinegar of graps and distillated water) on serum zinc levels in rabbits. Ankara Üniversitesi Veteriner Fakültesi Dergisi, 58: 11-16.

Karademir B. 2017. Investigation of some blood serum trace and macro mineral levels in fighting rabbits. 18-20 May 2017, University - Industry Collaboration: Sarajevo, Bosnia Herzegovina, pp: 396-404.

Karademir B, Yılmaz İ. 2018. E.coli (K99) kökenli buzağ ishalleri sırasında bazı iz ve makro minerallerin düzeylerinin durumları. I. International Iğdır congress on Multidisciplinary studies. 6-8 November 2018, İksad International Publishing House: Iğdır - Turkey, pp: 38-47.

Kincaid RL. 2000. Assessment of trace mineral status of ruminants: A review. Journal of Animal Science, 77: 1-10.

Koc E, Karademir B, Soomro N, Uzun F. 2018. The effects, both separate and Interactive, of smoking and tea consumption on urinary fluoride levels. Fluoride, 51: 84-96.

Kuru M, Karademir B, Oral H, Uzun F. 2018a. The effect of acute septic mastitis and clinical mastitis on serum levels of certain trace elements and macro minerals in cows. Erciyes Üniversitesi Veteriner Fakültesi Dergisi, 15: 11-16.

Kuru M, Karademir B, Oral H, Uzun F. 2018b. The effect on serum mineral levels of acute septic mastitis and clinical mastitis in cows. I. International Iğdır congress on Multidisciplinary studies. 6-7 November 2018, İksad International Publishing House: Iğdır Üniversitesi, IğdırTurkey, p: 415.

Lee FF, Bradley CW, Cain CL, White SD, Outerbridge C, Murphy LA, Mauldin EA. 2016. Localized parakeratotic hyperkeratosis in sixteen Boston terrier dogs. Veterinary Dermatology, 27: 384-396.

Malavolta M, Giacconi R, Piacenza F, Santarelli L, Cipriano C. 2010. Plasma copper/zinc ratio: an inflammatory/nutritional biomarker as predictor of all-cause mortality in elderly population. Biogerontology, 11: 309-319.

Ming PX, Ti YLX, Bulmer GS. 2006. Outbreak of Trichophyton verrucosum in China transmitted from cows to humans. Mycopathologia, 161: 225-228. 
Miraloglu M, Kurutas EB, Ozturk P, Arıcan O. 2016. Evaluation of local trace element status and 8-Iso-prostaglandin F2a concentrations in patients with Tinea pedis. Biological Procedures Online, 18. DOI: 10.1186/s12575-015-0030-x https://www.ncbi.nlm.nih.gov/pmc/articles/PMC4702401/pd f/12575_2015_Article_30.pdf (accessed 06 January 2019)

Montllor-Albalate C, Colin AE, Chandrasekharan B, Bolaji N, Anderson JL, Wayne OF, Reddi AR. 2018. Extramitochondrial $\mathrm{Cu} / \mathrm{Zn}$ superoxide dismutase $(\operatorname{Sod} 1)$ is dispensable for protection against oxidative stress but mediates peroxide signaling in Saccharomyces cerevisiae. Redox Biology, 21: 101064. DOI: 10.1016/j.redox. 2018.11.022 https://www.ncbi.nlm.nih.gov/pmc/articles/ PMC6302037/ (accessed 06 January 2019)

Nisbet C, Yarim GF, Ciftci G, Arslan HH, Ciftci A. 2006. Effects of trichophytosis on serum zinc levels in calves. Biological Trace Element Research, 113: 273-280.

Patiño-Herrera R, Catarino-Centeno R, Robles-Martínez M, Zarate MG, Flores AJC, Perez E. 2018. Antimycotic activity of zinc oxide decorated with silver nanoparticles against Trichophyton mentagrophytes. Powder Technology, 327: 381-391.

Pizent A, Pavlovic M, Jurasovic J, Dodig S, Pasalic D, Mujagic R. 2010. Antioxidants, trace elements and metabolic syndrome in elderly subjects. The Journal of Nutrition, Health \& Aging, 14: 866-871.

Potrykus J, Ballou ER, Childers DS, Brown AJP. 2014. Conflicting interests in the pathogen-host tug of war: fungal micronutrient scavenging versus mammalian nutritional immunity. PLoS Pathogens, 10: e1003910. DOI: 10.1371/journal.ppat.1003910 https://journals.plos.org/ plospathogens/article/file?id=10.1371/journal.ppat.1003910 \&type=printable (accessed 06 January 2019)

Robinett NG, Culbertson EM, Peterson RL, Sanchez H, Nett JE, Culotta VE. 2018. Exploiting the vulnerable active site of a copper-only superoxide dismutase to disrupt fungal pathogenesis. The Journal of Biological Chemistry, DOI: 10.1074/jbc.RA118.007095 http://www.jbc.org/content/early /2018/12/27/jbc.RA118.007095.full.pdf (accessed 06 January 2019)
Shams-Ghahfarokhi M, Mosleh-Tehrani F, Ranjbar-Bahadori S, Razzaghi-Abyaneh M. 2009. An epidemiological survey on cattle ringworm in major dairy farms of Mashhad city, Eastern Iran. Iranian J Microbiol, 1: 31-36. http://ijm.tums.ac.ir/index.php/ijm/article/view/27 (accessed 02 January 2019)

Sharma S, Kumar P, Joshi SC. 2012. An overview on fungal infection in diabetes. International Journal of Deccan Pharma and Life Sciences, 3: 110-125.

Shokri H, Khosravi AR. 2016. An epidemiological study of animals dermatomycoses in Iran. Journal De Mycologie Medicale, 26: 170-177.

Subramanian Vignesh K, Landero FJA, Porollo A, Caruso JA, Deepe GS. 2013. Zinc sequestration: arming phagocyte defense against fungal attack. PLoS Pathogens, 9: e1003815. DOI: 10.1371/journal.ppat.1003815 https://journals.plos.org/ plospathogens/article/file?id=10.1371/journal.ppat. 1003815 \&type=printable (accessed 06 January 2019)

Ural K, Karakurum MÇ, Duru Ö, Cingi CÇ, Haydardedeoğlu AE. 2009. Serum zinc concentrations in dogs with Microsporum canis dermatophytosis: a pilot study. Turkish Journal of Veterinary and Animal Sciences, 33: 279-283.

Wilson D, Citiulo F, Hube B. 2012. Zinc exploitation by pathogenic fungi. PLoS Pathogens, 8: e1003034. DOI: 10.1371/journal.ppat.1003034 https://journals.plos.org/ plospathogens/article/file?id=10.1371/journal.ppat. 1003034 \&type $=$ printable (accessed 06 January 2019)

Wu C, Feng Y, Shohag MJI, Lu LL, Wei YY, Gao C, Yang X. 2011. Characterization of (68) Zn uptake, translocation, and accumulation into developing grains and young leaves of high Zn-density rice genotype. Journal of Zhejiang University. Science. B, 12: 408-418

Yıldırım M, Çınar M, Öcal N, Yağcı BB, Askar S. 2010. Prevalence of Clinical Dermatophytosis and Oxidative Stress in Cattle. Journal of Animal and Veterinary Advances, 9: 1978-1982.

Zamani S, Sadeghi G, Yazdinia F, Moosa H, Pazooki, A. 2016. Epidemiological trends of dermatophytosis in Tehran, Iran: A five-year retrospective study. Journal De Mycologie Medicale, 26: 351-358. 